Article

\title{
Phenotypic and Genotypic Analysis of Resistant Helicobacter pylori Strains Isolated from Children with Gastrointestinal Diseases
}

\author{
Monika Maria Biernat ${ }^{1}$, Aldona Bińkowska ${ }^{2}$, Łukasz Łaczmański ${ }^{3}$, Paweł Biernat ${ }^{4}$, \\ Paweł Krzyżek ${ }^{5, *(D)}$ and Grażyna Gościniak ${ }^{5}$ (D) \\ 1 Department and Clinic of Haematology, Blood Neoplasms, and Bone Marrow Transplantation, \\ Wroclaw Medical University, 50-367 Wroclaw, Poland; monika.biernat@umed.wroc.pl \\ 2 2nd Military Field Hospital of the Polish Armed Forces, 50-984 Wroclaw, Poland; \\ aldona.binkowska@gmail.com \\ 3 Hirszfeld Institute of Immunology and Experimental Therapy, Polish Academy of Sciences, \\ 53-114 Wroclaw, Poland; lukasz@diagmol.com \\ 4 Department of Drugs Form Technology, Wroclaw Medical University, 50-556 Wroclaw, Poland; \\ pawel.biernat@umed.wroc.pl \\ 5 Department of Microbiology, Wroclaw Medical University, 50-368 Wroclaw, Poland; \\ grazyna.gosciniak@umed.wroc.pl \\ * Correspondence: krojcerpawel@gmail.com
}

Received: 3 September 2020; Accepted: 26 September 2020; Published: 27 September 2020

\begin{abstract}
Antibiotic resistance of Helicobacter pylori is currently a global issue. The aim of this study was to analyze actual antibiotic resistance rates of $H$. pylori strains isolated from children with primary infections and to compare the incidence of mutations that determine resistance to clarithromycin $(\mathrm{CH})$ and metronidazole (MET) in children with different clinical diagnoses. A total of $91 \mathrm{H}$. pylori strains were isolated from 108 children with primary infections. Drug susceptibility testing of the strains was performed using E-test method. Classical sequencing of DNA fragments was used to detect point mutations for $\mathrm{CH}$ and MET resistance. Resistance to $\mathrm{CH}$ was detected in $31 \%$ of isolated strains (28/91), while resistance to MET and CH was detected in 35\% (32/91) of strains. A2143G was the most frequently detected mutation and was dominant among strains isolated from children with peptic ulcer disease (80\%). Mutations in the $r d x A$ gene were found significantly more frequently among MET-resistant strains than MET-sensitive strains $\left(p=0.03, \mathrm{Chi}^{2}=4.3909\right)$. In children, a higher frequency of $H$. pylori multiresistant strains was observed compared with the previous study in the same area. Differences were found in the occurrence of point mutations among $H$. pylori strains resistant to $\mathrm{CH}$ isolated from children with different clinical diagnoses.
\end{abstract}

Keywords: Helicobacter pylori; children; antibiotic susceptibility; clarithromycin; metronidazole; point mutations

\section{Introduction}

Infections caused by Helicobacter pylori occur frequently in children. In most cases they are asymptomatic, but in a small percentage of infected children they may lead to peptic ulcer disease, erosive gastritis or duodenitis, which are all associated with abdominal pain and dyspepsia. Extragastric complications, such as iron-deficiency anemia and immune thrombocytopenic purpura, may also occur [1,2]. Serious complications-including gastric cancer or mucosa-associated lymphoid tissue (MALT) lymphoma-may occur many years after primary infection and are associated with a chronic inflammation process that leads to angiogenesis and pathologic changes in the gastric mucosa $[3,4]$. 
The association between $H$. pylori infection and gastroesophageal reflux disease (GERD) or inflammatory bowel disease (IBD) is controversial. Recent studies have shown that the frequency of $H$. pylori gastritis in children with IBD is lower than that in control individuals [5]. H. pylori infection may exacerbate GERD but may also have a protective role. An inverse relationship between the grade of esophagitis and the presence of $H$. pylori has been reported, which also shows that the presence of $H$. pylori seems to be beneficial and that it does not increase the grade of esophagitis [6,7].

Infections produced by $H$. pylori are only treated in symptomatic children and the eradication is based on complex antibiotic therapy according to the European Society of Pediatric Gastroenterology Hepatology and Nutrition (ESPGHAN)/North American Society for Pediatric Gastroenterology, Hepatology and Nutrition (NASPGHAN) guidelines [8]. In first-line therapy, protein-pump inhibitors (PPIs) and antibiotics from the macrolide group, mainly clarithromycin $(\mathrm{CH})$, are used in combination with amoxicillin (AMO) and nitroimidazole, including mainly metronidazole (MET) and less frequently tinidazole [8].

Failures of $H$. pylori infection therapy are mainly caused by increased antibiotic resistance, predominately to $\mathrm{CH}$. H. pylori resistance is widespread, and the frequency of its occurrence varies regionally. Resistance to $\mathrm{CH}$ results from point mutations in the domain $\mathrm{V}$ of the 23S rRNA gene of the $50 \mathrm{~S}$ ribosomal bacterial subunit, which lead to changes in protein conformation [9]. Three point mutations are of the greatest clinical importance: A2143G, A2142G and A2142C. The frequency of mutations varies depending on the geographic region. In the United States and Europe, the A2143G mutation is most frequently detected in strains resistant to $\mathrm{CH}$ [10]. Resistance to MET is mainly caused by mutations in the $r d x A$ gene, which encodes the oxygen insensitive RdxA nitroreductase. Mutations in the $r d x A$ gene may lead to a lack of enzymatic activity in this protein [11,12].

The aim of this study was to analyze the actual antibiotic resistance rates of $H$. pylori strains isolated from children with primary infections and to compare the incidence of mutations determining the resistance to $\mathrm{CH}$ and MET in children with different gastrointestinal diseases.

\section{Materials and Methods}

\subsection{Clinical Data}

A retrospective study was carried out on $91 \mathrm{H}$. pylori strains isolated from 108 children with primary infection, who were diagnosed and treated at the 2nd Department and Clinic of Pediatrics, Gastroenterology and Nutrition of the Wroclaw Medical University from April 2016 to March 2019. The strains were isolated from biopsy samples of gastric mucosa tissue, which were taken during endoscopic examinations of the upper gastrointestinal tract performed for clinical indications. Children with symptoms of nausea and vomiting, abdominal pain and gastrointestinal bleeding, in whom the infection had not been previously eradicated, were analyzed. The exclusion criteria were a history of previous $H$. pylori infection, antibiotic use, non-steroidal anti-inflammatory drug use or PPI use in the four weeks preceding the study. In children involved in the study, after obtaining the written consent of the parents, an endoscopic examination was performed to obtain both the gastric antrum and corpus for histopathological analysis (according to the updated Sydney classification). The approval of the Bioethics Committee of Wroclaw Medical University was obtained for the study (No 111/2017; 25 April 2017). The diagnosis of gastrointestinal disease was based on clinical, endoscopic and histologic findings. The diagnosis of $H$. pylori infection was based on histology and the culture of biopsy specimens. The bacteriological examination of gastric mucosa fragments taken during endoscopic examination was based on direct Gram staining, culture and biochemical differentiation (urease, oxidase and catalase) [13]. The reference strain, H. pylori J99, from the collection of the Department of Microbiology of Wroclaw Medical University was used in this study.

Initially, the biopsy samples collected during endoscopy for microbiology examination were placed in sterile saline $(0.15 \mathrm{M} \mathrm{NaCl})$ and processed within two hours. Then, biopsy samples were placed on two culture media: Columbia agar (Difco, Lublin, Poland) with 7\% hemolyzed horse blood 
and selective medium Columbia agar (Difco, Lublin, Poland) with 7\% hemolyzed horse blood enriched with a selective supplement (Oxoid, Le Pont de Claix, France). The supplement contained vancomycin $10 \mathrm{mg} / \mathrm{L}$, trimethoprim $10 \mathrm{mg} / \mathrm{L}$, cefsulodine $5 \mathrm{mg} / \mathrm{L}$, and amphotericin B $5 \mathrm{mg} / \mathrm{L}$. Incubation was performed under microaerophilic conditions $\left(10 \% \mathrm{CO}_{2}, 85 \% \mathrm{~N}_{2}, 5 \% \mathrm{O}_{2}\right)$ at $37^{\circ} \mathrm{C}$ for $3-5$ days. Isolated strains were identified on the basis of characteristic morphology of colonies and biochemical properties such as the ability to produce catalase, oxidase and urease. The epsilometer test (E-test) method was performed, as previously described [14,15]. H. pylori isolates were considered resistant when the minimum inhibitory concentration (MIC; $\mu \mathrm{g} / \mathrm{mL}$ ) was $\mathrm{CH}>0.5$, levofloxacin (LEV) $>1$, tetracycline $(\mathrm{TET})>1$, MET $>8$ and AMO $>0.12$ [13].

\subsection{Detection of H. pylori Genomic DNA Fragments}

Detection of $H$. pylori genomic DNA fragments by PCR using a previously described method [16]. DNA was isolated from $H$. pylori strains after $72 \mathrm{~h}$ of incubation with the column method using a Genomic Mini KIT (A\&A Biotechnology, Gdynia, Poland). We chose strains that were passaged on culture media only two or three times to reduce the risk of the high genetic variability of analyzed regions. After the centrifugation and removing the supernatant, the initial stage of cell lysis was initiated. The resulting suspension was transferred to columns and centrifuged for $1 \mathrm{~min}$ at $11,000 \times g$. Then, the filtrate was discarded, $500 \mu \mathrm{L}$ of washing buffer was added and centrifuged for $1 \mathrm{~min}$ at $11,000 \times g$. Again, the filtrate was discarded, $600 \mu \mathrm{L}$ of washing buffer was added and centrifuged for $1 \mathrm{~min}$ at $11,000 \times \mathrm{g}$. After discarding the filtrate to remove ethanol residues from the column, the samples were centrifuged at $11,000 \times g$ for $1 \mathrm{~min}$ and moved to an Eppendorf column. The final step was DNA elution from the column. After the addition of $100 \mu \mathrm{L}$ of the elution buffer heated to $70^{\circ} \mathrm{C}$ and a one minute incubation at room temperature, samples were centrifuged for $1 \mathrm{~min}$ at $11,000 \times g$ to obtain pure H. pylori DNA. The isolated DNA was stored at $-20^{\circ} \mathrm{C}$. polymerase chain reaction (PCR) for all strains was carried out on an MJ Research PTC-200 thermocycler. Complementary oligonucleotides to individual fragments of genomic DNA from H. pylori from Generi Biotech (Czech Republic) and PCR polymerase TaKaRa TaqTM hot start version from TAKARA Co (Japan) were used. The composition of the reaction mixture for the $23 \mathrm{~S}$ rRNA $H$. pylori fragment and reaction conditions were described elsewhere [13]. The reactions were carried out in a final volume of $20 \mu \mathrm{L} / \mathrm{sample}$. The size of the obtained product was $270 \mathrm{bp}$. The primers for the $r d x A$ gene were as follows: forward $5^{\prime}-3^{\prime}$ : GCA GGA GCA TCA GAT AGT TCT, reverse: $5^{\prime}-3^{\prime}$ : GGG ATT TTA TTG TAT GCT ACA A. The PCR conditions for $r d x A$ gene fragments were as follows: $10 \mathrm{~min}$ at $94^{\circ} \mathrm{C}$ for initial denaturation, followed by 35 cycles of $40 \mathrm{~s}$ at $94{ }^{\circ} \mathrm{C}, 40 \mathrm{~s}$ at $50^{\circ} \mathrm{C}$ and $1 \mathrm{~min}$ at $72{ }^{\circ} \mathrm{C}$, with a final round of $10 \mathrm{~min}$ at $72{ }^{\circ} \mathrm{C}$. The size of the $r d x A$ product obtained was $886 \mathrm{bp}$.

\subsection{Classical Sequencing of $H$. pylori DNA Fragments}

Classical sequencing of H. pylori DNA fragments by PCR as described elsewhere [16]. Briefly, in the first step, products were purified from the excess of ssDNA/oligonucleotides and dNTPs. Final products were subjected to classical sequencing with a BigDye ${ }^{\circledR}$ Terminator v3.1 cycle sequencing kit (Applied Biosystems, Foster City, CA, USA). The following were added to each sample: $0.5 \mu \mathrm{L}$ starter forward, $2.5 \mu \mathrm{L}$ BigDye, $2 \mu \mathrm{L}$ BigDye buffer and $9 \mu \mathrm{L}$ water. The reaction was carried out under the following conditions: $96^{\circ} \mathrm{C}$ for $1 \mathrm{~min}$, then 35 cycles of $96{ }^{\circ} \mathrm{C}$ for $10 \mathrm{~s}, 50^{\circ} \mathrm{C}$ for $5 \mathrm{~s}$ and $60^{\circ} \mathrm{C}$ for $5 \mathrm{~min}$. After the reaction was complete, the products were purified again from unbound reagents using FastAP alkaline thermosensitive phosphatase under the same conditions. A total of $5 \mu \mathrm{L}$ of the product and $9 \mu \mathrm{L}$ of formamide ( $\mathrm{Hi}_{-}-\mathrm{Di}^{\mathrm{TM}}$; Applied Biosystems, Foster City, CA, USA) were collected for separation on a denaturing polyacrylamide gel in a 3700 DNA analyzer sequencer. The results were analyzed with the FinchTV program. Sequenced DNA fragments of H. pylori strains were analyzed using the free FinchTV Version 1.5.0 application developed by the Geospiza research team. Each sequence was compared to the sequence of the H. pylori J99 and H. pylori 26695 reference strains, whose entire genomes are available on the GenBank website. 


\subsection{Statistical Analysis}

Statistical analyses were based on the assigned multi-divisional quantity tables and included comparisons within the groups (resistant-sensitive/male-female). First, general correlations between analyzed variables were assessed using correspondence analysis and the generalized analysis of main components. Statistical significance between nominal variables was evaluated by the chi-quadrant test with Yates' correction and the exact Fisher's test. The $p$ value of $\leq 0.05$ was considered statistically significant. All data were analyzed by STATISTICA v. 10.0 (StatSoft, Tulsa, OK, USA).

\section{Results}

In this study, we examined $91 \mathrm{H}$. pylori strains, which were isolated from gastric mucosa biopsy samples from 108 children ( 56 girls and 52 boys) with various gastrointestinal diseases (2-18 years, median 12.5 years). Of all tested H. pylori strains, 38.5\% (35/91) were isolated from patients with chronic gastritis, $15 \%$ (14/91) from patients with GERD, 16.5\% (15/91) from children with gastric and/or duodenal ulcer disease and 27/91 (30\%) from patients with other gastrointestinal diseases, such as coeliac disease (5/27), IBD (7/27), iron deficiency anemia (6/27), growth retardation (4/27) or allergies (5/27) (Table 1). Antrum-predominant gastritis was observed in GERD patients, whereas in patients with IBD the most frequent endoscopic diagnosis was gastroesophagitis. Among the $91 \mathrm{H}$. pylori strains isolated from children with primary infection, 32\% (29/91) were sensitive and 68\% (62/91) were resistant to at least one of the tested antibiotics. Among tested strains, 31\% of strains (28/91) were resistant to $\mathrm{CH}, 35 \%$ (32/91) were resistant to MET and $\mathrm{CH}$ and 2\% (2/91) were resistant to MET, CH and LEV. Strains resistant only to MET were not detected. All examined strains were sensitive to AMO and TET (Figure 1). CH-resistant strains were detected significantly more frequently in girls than boys $(p=0.032)$. Moreover, these strains were isolated more often than sensitive strains in patients with gastric/duodenal ulcers and GERD ( $p=0.03$ and $p=0.01$, respectively). Multiresistant strains, including those resistant to $\mathrm{CH}$ and MET, were detected significantly more frequently in boys with peptic ulcer disease and chronic gastritis $(p<0.05$, Table 1$)$.

Table 1. Characteristics of the examined group of children and drug sensitivity of $H$. pylori strains.

\begin{tabular}{|c|c|c|c|c|c|c|c|c|c|c|}
\hline \multirow{2}{*}{ H. pylori Strains } & \multicolumn{2}{|c|}{$\begin{array}{c}\text { All Patients } \\
\text { [Total] }(n=91)\end{array}$} & \multicolumn{2}{|c|}{$\begin{array}{c}\text { Chronic } \\
\text { Gastritis }(n=35)\end{array}$} & \multicolumn{2}{|c|}{$\begin{array}{l}\text { GERD } \\
(n=14)\end{array}$} & \multicolumn{2}{|c|}{$\begin{array}{l}\text { Gastric/Duodenal } \\
\text { Ulcer }(n=15)\end{array}$} & \multicolumn{2}{|c|}{$\begin{array}{l}\text { Other } * \\
(n=27)\end{array}$} \\
\hline & Male & Female & Male & Female & Male & Female & Male & Female & Male & Female \\
\hline $\begin{array}{l}\text { Susceptible to } \\
\text { CH }\end{array}$ & $\begin{array}{c}17 \\
(18.7 \%)\end{array}$ & $\begin{array}{c}12 \\
(13.2 \%)\end{array}$ & $\begin{array}{c}7 \\
(7.7 \%)\end{array}$ & $\begin{array}{c}5 \\
(5.5 \%)\end{array}$ & $\begin{array}{c}3 \\
(3.3 \%)\end{array}$ & $\begin{array}{c}1 \\
(1.1 \%)\end{array}$ & $\begin{array}{c}1 \\
(1.1 \%)\end{array}$ & $\begin{array}{c}0 \\
(0.0 \%)\end{array}$ & $\begin{array}{c}4 \\
(4.4 \%)\end{array}$ & $\begin{array}{c}8 \\
(8.8 \%)\end{array}$ \\
\hline \multirow[t]{2}{*}{ Resistant to $\mathrm{CH}$} & $\begin{array}{c}25 \\
(27.5 \%)\end{array}$ & $\begin{array}{c}37 \\
(40.7 \%)\end{array}$ & $\begin{array}{c}13 \\
(14.3 \%)\end{array}$ & $\begin{array}{c}10 \\
(11 \%)\end{array}$ & $\begin{array}{c}4 \\
(4.4 \%)\end{array}$ & $\begin{array}{c}6 \\
(6.6 \%)\end{array}$ & $\begin{array}{c}6 \\
(6.6 \%)\end{array}$ & $\begin{array}{c}8 \\
(8.8 \%)\end{array}$ & $\begin{array}{l}5 \\
(5.5 \%)\end{array}$ & $\begin{array}{c}10 \\
(11 \%)\end{array}$ \\
\hline & \multicolumn{2}{|c|}{$p=0.032$} & \multicolumn{2}{|c|}{$p>0.05$} & \multicolumn{2}{|c|}{$p=0.01$} & \multicolumn{2}{|c|}{$p=0.03$} & \multicolumn{2}{|c|}{$p>0.05$} \\
\hline $\begin{array}{c}\text { Susceptible to } \\
\mathrm{CH}+\mathrm{MET}\end{array}$ & $\begin{array}{c}17 \\
(18.7 \%)\end{array}$ & $\begin{array}{c}40 \\
(44 \%)\end{array}$ & $\begin{array}{c}7 \\
(7.7 \%)\end{array}$ & $\begin{array}{c}13 \\
(14.3 \%)\end{array}$ & $\begin{array}{c}3 \\
(3.3 \%)\end{array}$ & $\begin{array}{c}7 \\
(7.7 \%)\end{array}$ & $\begin{array}{c}1 \\
(1.1 \%)\end{array}$ & $\begin{array}{c}8 \\
(8.8 \%)\end{array}$ & $\begin{array}{c}4 \\
(4.4 \%)\end{array}$ & $\begin{array}{c}18 \\
(19.8 \%)\end{array}$ \\
\hline \multirow[t]{2}{*}{$\begin{array}{l}\text { Resistant to } \\
\text { CH + MET }\end{array}$} & $\begin{array}{c}25 \\
(27.5 \%)\end{array}$ & $\begin{array}{c}9 \\
(9.9 \%)\end{array}$ & $\begin{array}{c}13 \\
(14.3 \%)\end{array}$ & $\begin{array}{c}2 \\
(2.2 \%)\end{array}$ & $\begin{array}{c}4 \\
(4.4 \%)\end{array}$ & $\begin{array}{c}0 \\
(0 \%)\end{array}$ & $\begin{array}{c}6 \\
(6.6 \%)\end{array}$ & $\begin{array}{c}0 \\
(0 \%)\end{array}$ & $\begin{array}{l}5 \\
(5.5 \%)\end{array}$ & $\begin{array}{c}0 \\
(0 \%)\end{array}$ \\
\hline & \multicolumn{2}{|c|}{$p>0.05$} & \multicolumn{2}{|c|}{$p<0.01$} & \multicolumn{2}{|c|}{$p<0.01$} & \multicolumn{2}{|c|}{$p<0.01$} & \multicolumn{2}{|c|}{$p<0.01$} \\
\hline $\begin{array}{c}\text { Susceptible to } \\
\text { CH + MET + } \\
\text { LEV }\end{array}$ & $\begin{array}{c}42 \\
(46.1 \%)\end{array}$ & $\begin{array}{c}47 \\
(51.6 \%)\end{array}$ & $\begin{array}{c}20 \\
(22 \%)\end{array}$ & $\begin{array}{c}13 \\
(14.3 \%)\end{array}$ & $\begin{array}{c}7 \\
(7.7 \%)\end{array}$ & $\begin{array}{c}7 \\
(7.7 \%)\end{array}$ & $\begin{array}{c}7 \\
(7.7 \%)\end{array}$ & $\begin{array}{c}8 \\
(8.8 \%)\end{array}$ & $\begin{array}{c}9 \\
(9.9 \%)\end{array}$ & $\begin{array}{c}18 \\
(19.8 \%)\end{array}$ \\
\hline \multirow[t]{2}{*}{$\begin{array}{l}\text { Resistant to CH + } \\
\text { MET + LEV }\end{array}$} & $\begin{array}{c}0 \\
(0 \%)\end{array}$ & $\begin{array}{c}2 \\
(2.2 \%)\end{array}$ & $\begin{array}{c}0 \\
(0 \%)\end{array}$ & $\begin{array}{c}2 \\
(2.2 \%)\end{array}$ & $\begin{array}{c}0 \\
(0 \%)\end{array}$ & $\begin{array}{c}0 \\
(0 \%)\end{array}$ & $\begin{array}{c}0 \\
(0 \%)\end{array}$ & $\begin{array}{c}0 \\
(0 \%)\end{array}$ & $\begin{array}{c}0 \\
(0 \%)\end{array}$ & $\begin{array}{c}0 \\
(0 \%)\end{array}$ \\
\hline & \multicolumn{2}{|c|}{$p<0.01$} & \multicolumn{2}{|c|}{$p<0.01$} & \multicolumn{2}{|c|}{$p>0.05$} & \multicolumn{2}{|c|}{$p>0.05$} & \multicolumn{2}{|c|}{$p>0.05$} \\
\hline
\end{tabular}

$n=$ number, resistance to AMO and TET and resistance only to MET were not detected. Statistical analysis using multi-divisional tables included comparisons within groups (resistant-sensitive/male-female). * Other-celiac disease, IBD, iron deficiency anemia, growth retardation or allergies. 


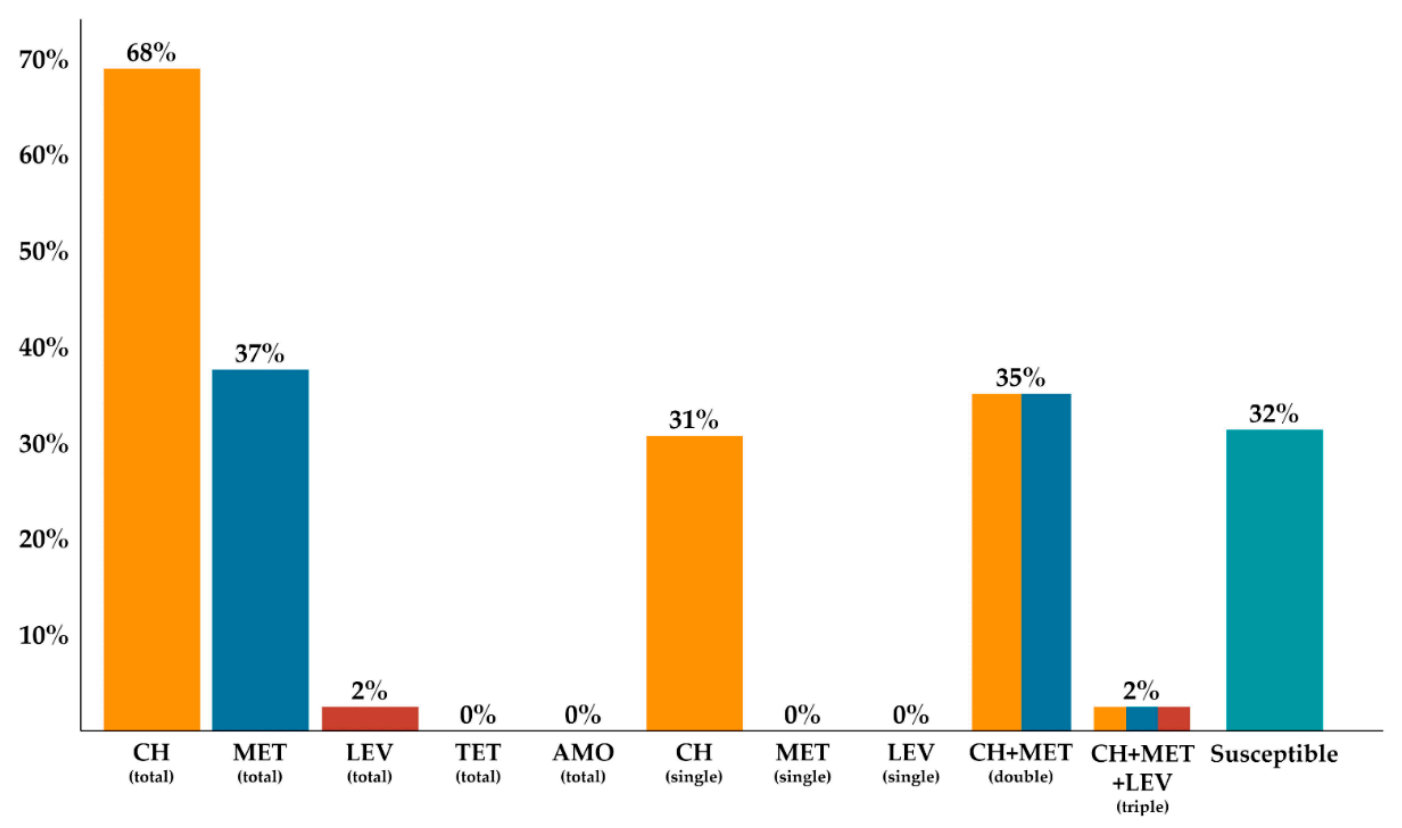

Figure 1. Resistance of Helicobacter pylori strains isolated from children with primary infections.

The mutation analysis of the $23 \mathrm{~S}$ rRNA gene was performed on $62 \mathrm{H}$. pylori strains resistant to $\mathrm{CH}$ and 29 sensitive to $\mathrm{CH}$. We chose strains that were passaged on culture media only two or three times to reduce the risk of the high genetic variability of analyzed regions [17]. Point mutations were detected in 55/62 resistant strains. Among them, 61\% (38/62) had the A2143G mutation, 44\% (27/62) had a single mutation, and the others had at least two mutations. Among strains resistant to $\mathrm{CH}, 11 \%(7 / 62)$ had the A2142G mutation, of which six strains had a single mutation and one strain had at least two mutations. In the remaining $10 \%(6 / 62)$ of resistant strains, no mutation was found. Among strains sensitive to $\mathrm{CH}, 7 \%(2 / 29)$ had the A2143G mutation, of which 3\% (1/29) had A2143G + A2174G mutations. Moreover, $17 \%$ (5/29) of strains had T2182C mutations. The remaining 72\% (21/29) of the sensitive strains had no mutations in the $23 \mathrm{~S}$ rRNA gene. Differences in detected point mutations were observed among strains isolated from children with different diseases. The CH-resistant strains with the A2143G mutation were isolated most often, regardless of the patient group (Table 2). In the group of patients with peptic ulcer disease, these strains constituted as much as $80 \%$ of all resistant strains, whereas in the group of patients with other diseases and GERD, they constituted approximately $40 \%$ of resistant strains; however, the differences were not statistically significant. Strains resistant to $\mathrm{CH}$ that had no nucleotide changes in the examined fragment of the $23 \mathrm{~S}$ rRNA gene and sensitive strains were nearly absent in patients with gastric and/or duodenal ulcer disease. In the group of patients with other gastrointestinal diseases, including IBD, coeliac disease and allergies, sensitive strains without mutations in the examined gene fragment were often present (33\%, 9/27). Strains resistant to $\mathrm{CH}$ with the $\mathrm{A} 2142 \mathrm{G}$ mutation were most often present in patients with GERD $(21 \%, 3 / 14)$, and in the remaining groups, they occurred in a small percentage of patients.

For the sequencing of the $r d x A$ gene, $19 \mathrm{H}$. pylori strains resistant to MET and 16 strains sensitive to MET were selected. The complete amino acid sequence of the $r d x A$ gene is presented in Figure 2 . Point mutations were present at 166 loci of the gene. In tested MET-resistant strains, point mutations were identified at the following positions: three at position 6 , one at 16; two at 25 ; seven at 31 ; one at 53; nineteen at 59; four at 62; two at 64; eleven at 68; one at 69 and 88; thirteen at 90; four at 97; three at 106; one at 108; three at 118; two at 131; one at 141,146, 168, 177 and 181; two at 200, 204 and 205; and one at 209. In strains sensitive to MET, the following mutations were identified: one at position 25 , four at 31 , fifteen at 59 , two at 62 , one at 64 ; thirteen at 68 , one at 88 , seven at 90 , eight at 97 , two at 98 and 106, one at 108, two at 115, seven at 118, seven at 131, two at 174 and 204 and three at 205. Many point mutations were found in both MET-sensitive and MET-resistant strains ( $387 \mathrm{vs.}$ 
400 , respectively; Table 3). The difference in the number of mutations between sensitive and resistant strains was statistically significant $\left(p=0.03, \chi^{2}=4.3909\right)$. Mutations that caused amino acid changes occurred with the same frequency among resistant and sensitive strains, while the main difference in the number of mutations was due to variability in regulatory regions of the gene. Resistant strains were more variable within the analyzed gene. Moreover, among resistant strains, stop codons formed as a result of mutations four times more often, which subsequently led to protein inactivation (Table 4). The occurrence of point mutations did not depend on the clinical diagnosis of the children from whom the strains were isolated.

Table 2. The occurrence of point mutations in the $23 \mathrm{~S}$ rRNA gene in H. pylori strains depending on the clinical diagnosis.

\begin{tabular}{|c|c|c|c|c|c|}
\hline \multirow[b]{2}{*}{ H. pylori Strains } & \multicolumn{4}{|c|}{ Clinical Diagnosis } & \multirow[b]{2}{*}{ Significance } \\
\hline & $\begin{array}{c}\text { Chronic Gastritis } \\
\quad(n=35)\end{array}$ & $\begin{array}{l}\text { GERD } \\
(n=14)\end{array}$ & $\begin{array}{c}\text { Peptic/Duodenal Ulcer } \\
(n=15)\end{array}$ & $\begin{array}{l}\text { Other }{ }^{*} \\
(n=27)\end{array}$ & \\
\hline $\mathrm{R} /$ without mutation & $11 \%(4)$ & $7 \%(1)$ & $0 \%(0)$ & $4 \%(1)$ & \multirow{7}{*}{$p>0.05$} \\
\hline R/A2142G & $8 \%(3)$ & $21 \%(3)$ & $7 \%(1)$ & $0 \%(0)$ & \\
\hline R/A2143G & $40 \%(14)$ & $36 \%(5)$ & $80 \%(12)$ & $44 \%(12)$ & \\
\hline $\mathrm{R} / \mathrm{T} 2182 \mathrm{C}$ & $6 \%(2)$ & $7 \%(1)$ & $7 \%(1)$ & $7 \%(2)$ & \\
\hline S/without mutation & $23 \%(8)$ & $21 \%(3)$ & $7 \%(1)$ & $33 \%(9)$ & \\
\hline S/A2143G & $3 \%(1)$ & $7 \%(1)$ & $0 \%(0)$ & $4 \%(1)$ & \\
\hline $\mathrm{S} / \mathrm{T} 2182 \mathrm{C}$ & $9 \%(3)$ & $0 \%(0)$ & $0 \%(0)$ & $7 \%(2)$ & \\
\hline
\end{tabular}

n-number; R-resistant; S-sensitive; *-Other celiac disease; IBD; iron deficiency anemia; growth retardation or allergies.

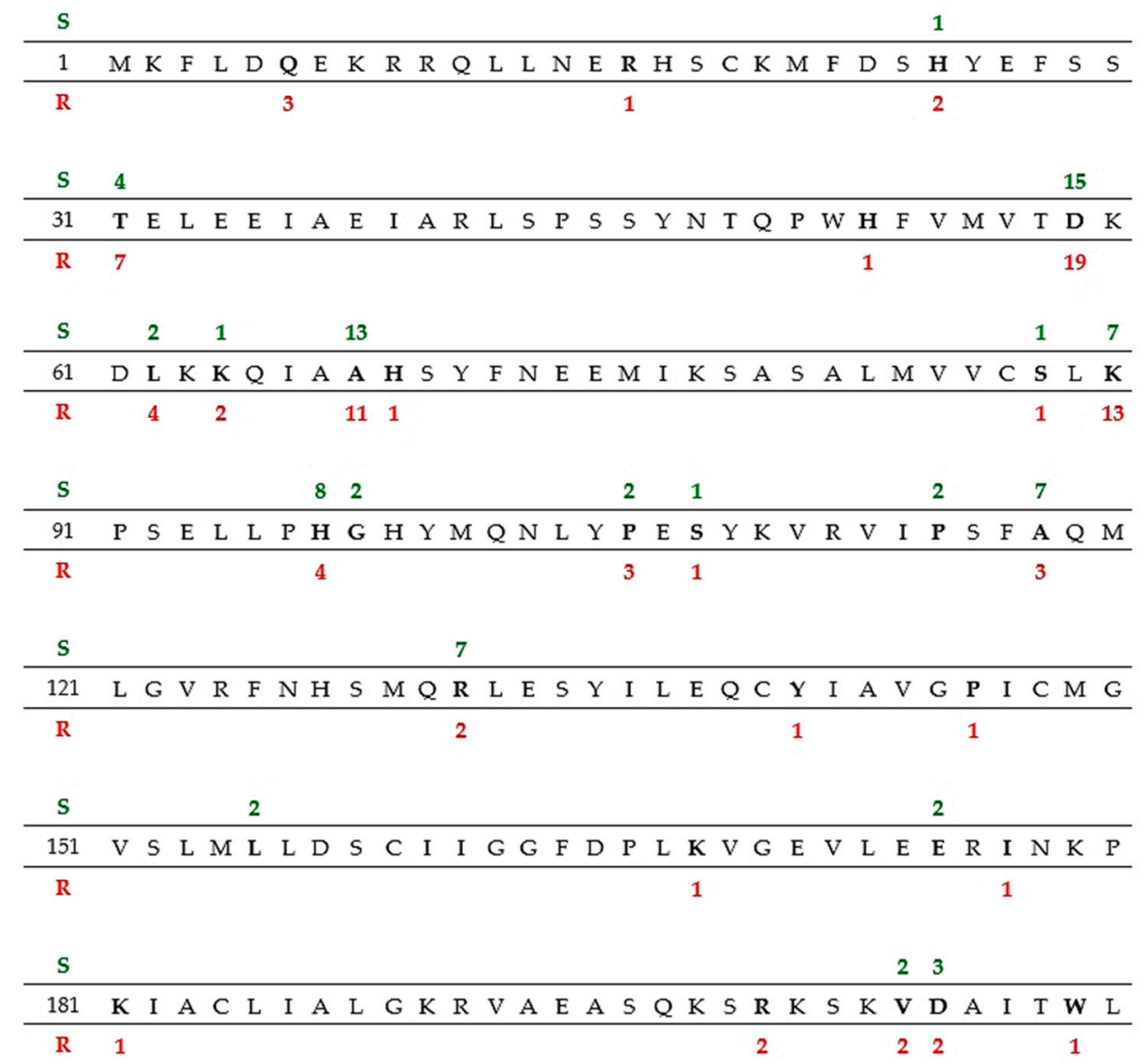

Figure 2. Sequence of the $r d x A$ gene of $H$. pylori 26695 strain; green numbers above and red numbers below indicate the number of mutations detected in the tested strains that were sensitive (S) and resistant (R) to MET, respectively. 
Table 3. Frequency of changes in $r d x A$ gene sequences obtained from 16 metronidazole (MET)-sensitives and 19 MET-resistant $H$. pylori strains.

\begin{tabular}{cccc}
\hline H. pylori Strains & Number of Mutations & $\begin{array}{c}\text { Number of Analyzed } \\
\text { Positions without Mutations }\end{array}$ & Significance \\
\hline $\begin{array}{c}\text { MET-sensitive } n=2656 \\
(16 \times 166)\end{array}$ & 387 & 2269 & $\begin{array}{c}p=0.0361 \\
\left(\mathrm{Chi}^{2}=4.3909\right)\end{array}$ \\
\hline $\begin{array}{c}\text { MET-resistant } n=3154 \\
(19 \times 166)\end{array}$ & 400 & 2754 & \\
\hline $\begin{array}{l}n=\text { number of total analyzed positions with potential mutations; } 16 \text { and 19 stands for the number of MET sensitive } \\
\text { and resistant strains, respectively; 166 stands for the number of loci of the gene. }\end{array}$
\end{tabular}

Table 4. Occurrence of point mutations in the $r d x A$ gene in tested H. pylori strains.

\begin{tabular}{ccccccc}
\hline $\begin{array}{c}\text { H. pylori } \\
\text { Strains }\end{array}$ & All Patients & Mutations & $\begin{array}{c}\text { Mutations } \\
\text { per Patient }\end{array}$ & $\begin{array}{c}\text { Stop } \\
\text { Mutations }\end{array}$ & $\begin{array}{c}\text { AA Changes } \\
\boldsymbol{n}(\%)\end{array}$ & $\begin{array}{c}\text { AA Changes } \\
\text { per Patient }\end{array}$ \\
\hline MET-sensitive & 16 & 387 & 24.2 & 1 & $82(21 \%)$ & 5 \\
\hline MET-resistant & 19 & 400 & 21 & 4 & $90(22.5 \%)$ & 4.7 \\
\hline
\end{tabular}

Children from whom sensitive strains were isolated were treated for 7-14 days with standard eradication regimens according to the ESPGHAN/NASPGHAN guidelines [8], whereas children infected with strains resistant to $\mathrm{CH}$ or MET or double-resistant strains were treated with sequential therapy. The eradication efficacy was assessed with the rapid urease test (RUT) or endoscopy if necessary. The eradication efficacy was $100 \%$ for sequential therapy for $\mathrm{CH}$-resistant strains and $72-75 \%$ for MET-resistant or double-resistant strains (data not shown).

\section{Discussion}

The incidence of $H$. pylori infection in children, despite better knowledge of its pathogenesis and therapy regimens, is still high (approximately 33\%), which was demonstrated in two meta-analyses [18]. In Poland, the incidence of infection is similar, counting for approximately 30\% [19]. The therapy regimens based on PPIs and two antibiotics (MET or $\mathrm{CH}$ and AMO) are used according to the ESPGHAN/NASPGHAN guidelines. The use of $\mathrm{CH}$ should be limited to cases where the sensitivity to this antibiotic has been confirmed, however, due to global increases in antibiotic resistance, eradication rates are unsatisfactorily low $[8,20]$. A recent multicenter meta-analysis involving 17 pediatric centers from 14 European countries demonstrated that resistance to $\mathrm{CH}$ reached $24 \%$, resistance to MET was equal to $25 \%$, resistance to both antibiotics $(\mathrm{CH}+\mathrm{MET})$ reached $7 \%$, whereas resistance to amoxicillin was low and did not exceed 1\% [20]. Resistance to $\mathrm{CH}$ shows marked differences depending on the geographical region and is caused by the high consumption of this antibiotic in children, mainly due to respiratory tract infections $[1,8]$. Our study shows that in our region single resistance to $\mathrm{CH}$ has doubled from $17.1 \%$ in the period from $2008-2012$ to $31 \%$ in the current study, as was demonstrated in previous observations in a similar group of patients [13]. Analogous findings were observed by Shu et al. who showed a significant increase in CH resistance from 11\% in 2012 to $26 \%$ in 2014 [21]. Similar increasing trends in $\mathrm{CH}$ resistance in children was observed by other authors from Europe and Asia [22-24]. The single resistance of $\mathrm{H}$. pylori strains isolated from children to MET in our region remains stable, but high (from $28.6 \%$ in the period from 2008-2012 to current 31\%), similar to other European countries $(15-30 \%)$, but it is much higher in Iran (60\%) and in China (68\%) [13,20-22,25-28]. The increase in dual resistance to $\mathrm{CH}$ and MET from $14 \%$ to $35 \%$ detected in our study is particularly alarming. Shu et al. recently showed a significant increase in resistance rates for $\mathrm{CH}$, MET and double-resistance to $\mathrm{CH}$ and MET in children in China [21]. Similar observations were made by researchers from Turkey [29]. In Poland, due to high resistance to $\mathrm{CH}(>15 \%)$, the empirical use of PPIs, MET and AMO in first-line therapy is a standard treatment, although at our center, attempts at targeted treatment based on results 
of susceptibility testing have been undertaken for several years [30]. Multiresistant strains, including those resistant to $\mathrm{CH}$ and MET, were detected significantly more frequently in boys with peptic ulcer disease and chronic gastritis than in girls $(p<0.05)$. Sex-related differences in prevalence and resistance of H. pylori were reported in the literature [20]. These differences may be explained by exposure to antibiotics and health habits in boys and girls. Antibiotics which are used for other indications, mainly respiratory tract infections, more frequently in boys, could contribute to cure rate of $H$. pylori infection also. It seems that the occurrence of dual resistance carries a high risk of first-line therapy failure, and it is necessary to implement methods of susceptibility testing before treatment. Due to the limited use of $H$. pylori culture methods, which are frequently unavailable, and time consuming, molecular methods of drug susceptibility testing seem to be a promising alternative.

Our study showed important differences in detected point mutations among strains isolated from children with different diseases, although they were not statistically significant, which may have been due to the small number of patients in all examined groups. The most frequent mutation among strains resistant to $\mathrm{CH}$ was $\mathrm{A} 2143 \mathrm{G}$, which was detected more often among resistant than sensitive strains $(44 \%$ vs. $7 \%$ ). Strains with this mutation were isolated most frequently in all groups of patients; moreover, this mutation was dominant in children with gastric/duodenal ulcer disease. The occurrence of the A2143G mutation among strains isolated in Poland was also confirmed by other authors [31]. Additionally, this mutation seems to be dominant among H. pylori strains worldwide [32-35]. These findings have important clinical implications. Francavilla et al. demonstrated that the eradication rate of strains with the A2143G mutation was very low, reaching approximately $50 \%$; hence, the presence of this mutation carries a higher risk of treatment failure [36], while the eradication rate of strains with $\mathrm{A} 2142 \mathrm{G}$ mutation reaches approximately $80 \%$. In our study, strains resistant to $\mathrm{CH}$ with the A2142G mutation were most often present in patients with GERD $(27 \%, 4 / 15)$. This is an important finding, because according to the guidelines, all children with $H$. pylori infection and GERD who require long-term PPI treatment should achieve eradication [1]. It was shown that for strains with the A2142G mutation, the eradication rates reached $80 \%$. These strains, as shown by our previous observations and by researchers from Asia, had lower MIC values than A2143G strains [16,33,34]. Strains sensitive to $\mathrm{CH}$ with the A2143G or T2182C mutation were very rare or not detected. The cause of this phenomenon is unknown. The T2182C mutation is responsible for low level of resistance to clarithromycin. It can be assumed that the $\mathrm{T} 2182 \mathrm{C}$ mutation does not have a great importance in the resistance mechanism. Hence, it is possible another independent resistance mechanism is necessary for the presence of phenotypic resistance. Moreover, considering the presence of the A2143G mutation in these strains, the existence of another mechanism is possible, which only in combination with A2143G mutation, gives a resistance phenotype. Another explanation may be that isolated strains can consist of mixed bacterial population in the gastric specimens, i.e., the specimens may have both susceptible and resistant strains $[9,25]$. We speculate that in children with peptic ulcer disease primary H. pylori infections may be caused by strains with a different drug susceptibility profile than in children with IBD and GERD. This phenomenon requires further study, especially since data are scarce in the literature. We did not find any mutations in the $23 \mathrm{~S}$ rRNA gene in approximately $10 \%$ of $\mathrm{H}$. pylori strains resistant to $\mathrm{CH}$, which may suggest another cause of resistance. Apart from $23 \mathrm{~S}$ rRNA mutations, the mechanism of resistance to $\mathrm{CH}$ may be related to the expression of efflux resistance-nodulation division (RND) pumps and the ability to form biofilms, which seem to play a role not only in the acquisition of $\mathrm{CH}$ resistance, but also to lead to the formation of multiresistant strains [9,37]. Moreover, it was demonstrated that $H$. pylori strains in which A2143G or A2142G mutations were identified were more frequently found in the structure of the biofilms than in plankton [38].

H. pylori resistance to MET is a complex phenomenon and is likely associated with the inactivation of the $r d x A$ and/or frxA genes [9,12]. It is assumed that the main cause of $H$. pylori resistance is the mutation of the $r d x A$ gene, whereas mutations in the frx $A$ gene increase the degree of resistance $[39,40]$. According to some researchers, resistance to MET results from the deficiency or absence of one of the products of the $r d x A$ and $f r x A$ genes or both simultaneously [40]. All changes were distributed 
throughout the genes, which was also seen in our study. Some single point mutations resulted in the formation of stop codons and were four times more common among MET-resistant strains than MET-sensitive strains. Some authors reported that up to $40 \%$ of $r d x A$ point mutations cause the formation of stop codons, which consequently shortens the length of polypeptide, which can be quickly degraded [39]. In this study, mutations in the same positions of the $r d x A$ gene occurred in MET-resistant and MET-sensitive strains. However, Tanih et al. observed the Glu27Val mutation was characteristic of MET-sensitive strains [41]. Apart from that, there were many mutations in MET-resistant strains that were already described by other authors, e.g., Arg115Ile, Arg16His, Ser111Leu and Arg16Cys [41,42]. The knowledge of RdxA protein structure enables the interpretation of mutations, which may cause the loss of NADPH reductase function [11]. Another cause of MET resistance may be outer efflux proteins (OEP) in the cell membrane, which may pump out various substances from the cell. The inhibition of OEP proteins (HP0605 and HP0971) in MET-resistant strains resulted in higher sensitivity to the drug [9]. Moreover, some researchers have suggested that several mutations in Fur proteins may influence the sensitivity to MET by affecting the balance of Fur proteins, resulting in the expression of genes controlling cellular redox potential and the elimination of active MET products [43]. Moreover, Binh et al. reported a new rpsU gene in H. pylori strains encoding the ribosomal protein 30S S21, which is probably associated with MET resistance [39].

Our study has some limitations. We did not analyze other resistance mechanisms such as the efflux pump genes and mutations in the frxA gene, which may also be relevant for resistance to MET. Moreover, the study did not analyze the eradication rates in the examined children because we were unable to collect follow-up information about the eradication regimen and its effectiveness in all children. The study was a single-center analysis, which is why the results cannot necessarily be extrapolated to other centers. However, to our knowledge, this is the first study in Poland to analyze mutations determining resistance to MET in a pediatric population and one of few studies in which the relationship between the occurrence of certain mutations in H. pylori strains and the type of gastrointestinal disease has been examined in children.

\section{Conclusions}

In conclusion, this study showed an increasing trend in the presence of $\mathrm{CH}$ resistance and the occurrence of multiresistant $H$. pylori strains in children with primary infections, while resistance rates to MET were stable. We showed significant differences in detected point mutations related to resistance to $\mathrm{CH}$ among strains isolated from children with different gastrointestinal diseases. The most common mutation associated with resistance to $\mathrm{CH}$ was A2143G, which was dominant among H. pylori strains isolated from children with peptic/duodenal ulcer disease (80\%). Mutations in the $r d x A$ gene occurred significantly more frequently among MET-resistant strains than MET-sensitive strains, and the difference in the number of mutations resulted from variability in regulatory regions of the $r d x A$ gene.

Author Contributions: M.M.B., A.B. and G.G. designed the study and were responsible for data analysis and interpretation; G.G., P.K. and M.M.B. performed culturing and antibiotic testing; A.B. and Ł.Ł. conducted the PCR analysis and sequencing; P.B. was responsible for statistical analyses; M.M.B. wrote the manuscript; all authors participated in editing and critical review of the manuscript. All authors have read and agreed to the published version of the manuscript.

Funding: The study was supported by Wroclaw Medical University grant No: SUB.A130.19.021. The funders had no role in study design, data collection and analysis, decision to publish or preparation of the manuscript.

Acknowledgments: We would like to thank Barbara Iwańczak for long-term cooperation.

Conflicts of Interest: The authors declare no conflict of interest. 


\section{References}

1. Malfertheiner, P.; Venerito, M.; Schulz, C. Helicobacter pylori Infection: New Facts in Clinical Management. Curr. Treat. Opt. Gastroenterol. 2018, 16, 605-615. [CrossRef] [PubMed]

2. Okuda, M.; Lin, Y.; Kikuchi, S. Helicobacter pylori Infection in Children and Adolescents. Adv. Exp. Med. Biol. 2019, 1149, 107-120. [PubMed]

3. Kori, M.; Daugule, I.; Urbonas, V. Helicobacter pylori and Some Aspects of Gut Microbiota in Children. Helicobacter 2018, 23, e12524. [CrossRef]

4. Wroblewski, L.E.; Peek, R.M. Helicobacter pylori, Cancer, and the Gastric Microbiota. Adv. Exp. Med. Biol. 2016, 908, 393-408. [PubMed]

5. Roka, K.; Roubani, A.; Stefanaki, K.; Panayotou, I.; Roma, E.; Chouliaras, G. The Prevalence of Helicobacter pylori Gastritis in Newly Diagnosed Children with Inflammatory Bowel Disease. Helicobacter 2014, 19, 400-405.

6. Lupu, V.V.; Ignat, A.; Ciubotariu, G.; Ciubară, A.; Moscalu, M.; Burlea, M. Helicobacter pylori Infection and Gastroesophageal Reflux in Children. Dis. Esophagus 2016, 29, 1007-1012. [PubMed]

7. Yucel, O. Interactions between Helicobacter pylori and Gastroesophageal Reflux Disease. Esophagus 2019, 16, 52-62. [CrossRef] [PubMed]

8. Jones, N.L.; Koletzko, S.; Goodman, K.; Bontems, P.; Cadranel, S.; Casswall, T.; Czinn, S.; Gold, B.D.; Guarner, J.; Elitsur, Y.; et al. Joint ESPGHAN/NASPGHAN Guidelines for the Management of Helicobacter pylori in Children and Adolescents (Update 2016). J. Pediatr. Gastroenterol. Nutr. 2017, 64, 991-1003. [CrossRef] [PubMed]

9. De Francesco, V.; Zullo, A.; Hassan, C.; Giorgio, F.; Rosania, R.; Ierardi, E. Mechanisms of Helicobacter pylori Antibiotic Resistance: An Updated Appraisal. World J. Gastrointest. Pathophysiol. 2011, 2, 35-41.

10. De Francesco, V.; Margiotta, M.; Zullo, A.; Hassan, C.; Troiani, L.; Burattini, O.; Stella, F.; Di Leo, A.; Russo, F.; Marangi, S.; et al. Clarithromycin-Resistant Genotypes and Eradication of Helicobacter pylori. Ann. Intern. Med. 2006, 144, 94-100. [CrossRef]

11. Martínez-Júlvez, M.; Rojas, A.L.; Olekhnovich, I.; Angarica, V.E.; Hoffman, P.S.; Sancho, J. Structure of RdxA-An Oxygen-Insensitive Nitroreductase Essential for Metronidazole Activation in Helicobacter pylori. FEBS J. 2012, 279, 4306-4317. [PubMed]

12. Hoffman, P.S.; Goodwin, A.; Johnsen, J.; Magee, K.; Van Zanten, S.J.O.V. Metabolic Activities of Metronidazole-Sensitive and -Resistant Strains of Helicobacter pylori: Repression of Pyruvate Oxidoreductase and Expression of Isocitrate Lyase Activity Correlate with Resistance. J. Bacteriol. 1996, 178, 4822-4829. [CrossRef] [PubMed]

13. Gościniak, G.; Biernat, M.; Grabińska, J.; Bińkowska, A.; Poniewierka, E.; Iwańczak, B. The Antimicrobial Susceptibility of Helicobacter pylori Strains Isolated from Children and Adults with Primary Infection in the Lower Silesia Region, Poland. Polish J. Microbiol. 2014, 63, 57-61. [CrossRef]

14. Glupczynski, Y.; Mégraud, F.; Lopez-Brea, M.; Andersen, L. European Multicentre Survey of In Vitro Antimicrobial Resistance in Helicobacter pylori. Eur. J. Clin. Microbiol. Infect. Dis. 2001, 20, 820-823. [CrossRef]

15. Glupczynski, Y.; Broutet, N.; Cantagrel, A.; Andersen, L.; Alarcon, T.; López-Brea, M.; Mégraud, F. Comparison of the E test and Agar Dilution Method for Antimicrobial Suceptibility Testing of Helicobacter pylori. Eur. J. Clin. Microbiol. Infect. Dis. 2002, 21, 549-552.

16. Bińkowska, A.; Biernat, M.M.; Łaczmański, Ł.; Gościniak, G. Molecular Patterns of Resistance Among Helicobacter pylori Strains in South-Western Poland. Front. Microbiol. 2018, 9, 3154. [CrossRef]

17. Hanafi, A.; Lee, W.C.; Loke, M.F.; Teh, X.; Shaari, A.; Dinarvand, M.; Lehours, P.; Mégraud, F.; Ruey Leow, A.H.; Vadivelu, J.; et al. Molecular and Proteomic Analysis of Levofloxacin and Metronidazole Resistant Helicobacter pylori. Front. Microbiol. 2016, 7, 2015. [CrossRef]

18. Zabala Torrres, B.; Lucero, Y.; Lagomarcino, A.J.; Orellana-Manzano, A.; George, S.; Torres, J.P.; O’Ryan, M. Review: Prevalence and Dynamics of Helicobacter pylori Infection during Childhood. Helicobacter 2017, 22, e12399.

19. Iwańczak, B.M.; Buchner, A.M.; Iwańczak, F. Clinical Differences of Helicobacter pylori Infection in Children. Adv. Clin. Exp. Med. 2017, 26, 1131-1136. [CrossRef] 
20. Koletzko, S.; Richy, F.; Bontems, P.; Crone, J.; Kalach, N.; Monteiro, M.L.; Gottrand, F.; Celinska-Cedro, D.; Roma-Giannikou, E.; Orderda, G.; et al. Prospective Multicentre Study on Antibiotic Resistance of Helicobacter pylori Strains Obtained from Children Living in Europe. Gut 2006, 55, 1711-1716. [CrossRef]

21. Shu, X.; Yin, G.; Liu, M.; Peng, K.; Zhao, H.; Jiang, M. Antibiotics Resistance of Helicobacter pylori in Children with Upper Gastrointestinal Symptoms in Hangzhou, China. Helicobacter 2018, 23, e12481. [CrossRef] [PubMed]

22. Dargiene, G.; Kupcinskas, J.; Jonaitis, L.; Vezbavicius, M.; Kadusevicius, E.; Kupcinskiene, E.; Frandsen, T.H.; Kucinskiene, R.; Kupcinskas, L.; Andersen, L.P. Primary Antibiotic Resistance of Helicobacter pylori Strains among Adults and Children in a Tertiary Referral Centre in Lithuania. APMIS 2018, 126, 21-28. [CrossRef] [PubMed]

23. Boyanova, L.; Gergova, G.; Evstatiev, I.; Spassova, Z.; Kandilarov, N.; Yaneva, P.; Markovska, R.; Mitov, I. Helicobacter pylori Resistance to Six Antibiotics by Two Breakpoint Systems and Resistance Evolution in Bulgaria. Infect. Dis. 2016, 48, 56-62. [CrossRef] [PubMed]

24. Seo, J.H.; Jun, J.S.; Yeom, J.S.; Park, J.S.; Youn, H.S.; Ko, G.H.; Baik, S.C.; Lee, W.K.; Cho, M.J.; Rhee, K.H. Changing Pattern of Antibiotic Resistance of Helicobacter pylori in Children during 20 years in Jinju, South Korea. Pediatr. Int. 2013, 55, 332-336. [CrossRef] [PubMed]

25. Butenko, T.; Jeverica, S.; Orel, R.; Homan, M. Antibacterial Resistance and the Success of Tailored Triple Therapy in Helicobacter pylori Strains Isolated from Slovenian Children. Helicobacter 2017, 22, e12400. [CrossRef]

26. Pastukh, N.; Peretz, A.; Brodsky, D.; Isakovich, N.; Azrad, M.; On, A. Antimicrobial Susceptibility of Helicobacter pylori Strains Isolated from Children in Israel. J. Glob. Antimicrob. Resist. 2018, 12, 175-178. [CrossRef]

27. Megraud, F.; Coenen, S.; Versporten, A.; Kist, M.; Lopez-Brea, M.; Hirschl, A.M.; Andersen, L.P.; Goossens, H.; Glupczynski, Y.; Study Group Participants. Helicobacter pylori Resistance to Antibiotics in Europe and Its Relationship to Antibiotic Consumption. Gut 2013, 62, 34-42. [CrossRef]

28. Mahmoudi, S.; Mamishi, S.; Banar, M.; Keshavarz Valian, S.; Bahador, A.; Najafi, M.; Farahmand, F.; Pourakbari, B. Antibiotic Susceptibility of Helicobacter pylori Strains Isolated from Iranian Children: High Frequency of A2143G Point Mutation Associated with Clarithromycin Resistance. J. Glob. Antimicrob. Resist. 2017, 10, 131-135. [CrossRef]

29. Güven, B.; Gülerman, F.; Kaçmaz, B. Helicobacter pylori Resistance to Clarithromycin and Fluoroquinolones in a Pediatric Population in Turkey: A Cross-Sectional Study. Helicobacter 2019, 24, e12581. [CrossRef]

30. Iwańczak, B.M.; Borys-Iwanicka, A.; Biernat, M.; Gościniak, G. Assessment of Sequential and Standard Triple Therapy in Treatment of Helicobacter pylori Infection in Children Dependent on Bacteria Sensitivity to Antibiotics. Adv. Clin. Exp. Med. 2016, 25, 701-708. [CrossRef]

31. Klesiewicz, K.; Nowak, P.; Karczewska, E.; Skiba, I.; Wojtas-Bonior, I.; Sito, E.; Budak, A. PCR-RFLP Detection of Point Mutations A2143G and A2142G in 23S rRNA Gene Conferring Resistance to Clarithromycin in Helicobacter pylori Strains. Acta Biochim. Pol. 2014, 61, 311-315. [CrossRef] [PubMed]

32. Raymond, J.; Burucoa, C.; Pietrini, O.; Bergeret, M.; Decoster, A.; Wann, A.; Dupont, C.; Kalach, N. Clarithromycin Resistance in Helicobacter pylori Strains Isolated from French Children: Prevalence of the Different Mutations and Coexistence of Clones Harboring Two Different Mutations in the Same Biopsy. Helicobacter 2007, 12, 157-163. [CrossRef] [PubMed]

33. Zhang, Y.; Wen, Y.; Xiao, Q.; Zheng, W.; Long, G.; Chen, B.; Shu, X.; Jiang, M. Mutations in the Antibiotic Target Genes Related to Clarithromycin, Metronidazole and Levofloxacin Resistance in Helicobacter pylori Strains from Children in China. Infect. Drug Resist. 2020, 13, 311-322. [CrossRef] [PubMed]

34. Seo, S.I.; Do, B.J.; Kang, J.G.; Kim, H.S.; Jang, M.K.; Kim, H.Y.; Shin, W.G. Helicobacter pylori Eradication According to Sequencing-Based 23S Ribosomal RNA Point Mutation Associated with Clarithromycin Resistance. J. Clin. Med. 2019, 9, 54. [CrossRef] [PubMed]

35. Pourakbari, B.; Mahmoudi, S.; Parhiz, J.; Sadeghi, R.H.; Monajemzadeh, M.; Mamishi, S. High Frequency of Metronidazole and Clarithromycin-Resistant Helicobacter pylori in Formalin-Fixed, Paraffin-Embedded Gastric Biopsies. Br. J. Biomed. Sci. 2018, 75, 61-65. [CrossRef] [PubMed]

36. Francavilla, R.; Lionetti, E.; Castellaneta, S.; Margiotta, M.; Piscitelli, D.; Lorenzo, L.; Cavallo, L.; Ierardi, E. Clarithromycin-Resistant Genotypes and Eradication of Helicobacter pylori. J. Pediatr. 2010, 157, $228-232$. [CrossRef] 
37. Hu, Y.; Zhu, Y.; Lu, N.H. Novel and Effective Therapeutic Regimens for Helicobacter pylori in an Era of Increasing Antibiotic Resistance. Front. Cell. Infect. Microbiol. 2017, 7, 168. [CrossRef]

38. Yonezawa, H.; Osaki, T.; Hojo, F.; Kamiya, S. Effect of Helicobacter pylori Biofilm Formation on Susceptibility to Amoxicillin, Metronidazole and Clarithromycin. Microb. Pathog. 2019, 132, 100-108. [CrossRef]

39. Binh, T.T.; Suzuki, R.; Trang, T.T.H.; Kwon, D.H.; Yamaoka, Y. Search for Novel Candidate Mutations for Metronidazole Resistance in Helicobacter pylori Using Next-Generation Sequencing. Antimicrob. Agents Chemother. 2015, 59, 2343-2348. [CrossRef]

40. Marais, A.; Bilardi, C.; Cantet, F.; Mendz, G.L.; Mégraud, F. Characterization of the Genes rdxA and frxA Involved in Metronidazole Resistance in Helicobacter pylori. Res. Microbiol. 2003, 154, 137-144. [CrossRef]

41. Tanih, N.F.; Ndip, L.M.; Ndip, R.N. Characterisation of the Genes Encoding Resistance to Metronidazole (rdxA and frxA) and Clarithromycin (the 23S-rRNA Genes) in South African Isolates of Helicobacter pylori. Ann. Trop. Med. Parasitol. 2011, 105, 251-259. [CrossRef] [PubMed]

42. Kwon, D.H.; Hulten, K.; Kato, M.; Kim, J.J.; Lee, M.; El-Zaatari, F.A.K.; Osato, M.S.; Graham, D.Y. DNA Sequence Analysis of rdxA and frxA from 12 Pairs of Metronidazole-Sensitive and -Resistant Clinical Helicobacter pylori Isolates. Antimicrob. Agents Chemother. 2001, 45, 2609-2615. [CrossRef] [PubMed]

43. Choi, S.S.; Chivers, P.T.; Berg, D.E. Point Mutations in Helicobacter pylori's fur Regulatory Gene that Alter Resistance to Metronidazole, a Prodrug Activated by Chemical Reduction. PLoS ONE 2011, 6, e18236. [CrossRef] [PubMed]

(C) 2020 by the authors. Licensee MDPI, Basel, Switzerland. This article is an open access article distributed under the terms and conditions of the Creative Commons Attribution (CC BY) license (http://creativecommons.org/licenses/by/4.0/). 